\title{
APRESENTAÇÃO - HANNAH ARENDT: PENSAR SEM CORRIMÃOS
}

\author{
Carlos Roberto de Carvalho ${ }^{1}$ \\ Francisco Moraes $^{2}$ \\ Lasciate ogni speranza, voi ch'entrate \\ (Dante Alighieri, Divina Comédia, Canto III do Inferno, $9^{\circ}$ verso)
}

Abandonai toda esperança, vós que aqui entrais!

Com esse dossiê, convidamos aos leitores a visitarem a escuridão infernal destes tempos sombrios de que ao longo de toda sua obra nos fala Hannah Arendt; convidamos a visitar, em cada texto aqui publicado, o pensamento de uma importante pensadora do século XX, pensamento esse que, a nosso ver, pinta e desenha o cenário contemporâneo da divina comédia humana; convidamos todos a pisarem firme no palco de suas palavras, assim como nos aconselharia Drummond, convidamos a penetrar "... surdamente no reino das palavras" e a ouvir como se ouvisse pela primeira vez, como se fora uma criança que nascera deveras.

Lasciate ogni speranza, voi ch'entrate!- canta a voz de Dante

A voz de Dante é o texto completo. É todo o sentido deste dossiê. Apenas o temor da falta de entendimento é que nos obriga a escrever mais do que já foi escrito. Em nosso entendimento, trata-se de um aviso, afinal: Vivemos "tempos de absoluta depuração"!

Em cada texto que aqui visitarem, ouvirão a voz desassossegada do pensamento, que luta, de peito aberto, com o impronunciável. São textos de homens e mulheres no tempo dos homens sombrios. Por isso, ousamos dizer: o importante é pensar e pensar sem corrimãos. Daí nasce a intenção deste dossiê, fruto do trabalho de muitos pensadores, filósofos, professores, brasileiros e estrangeiros que generosamente ouviram o nosso apelo.

Neste momento, nossa proposta não poderia ser outra: trazer para a cena contemporânea um pensamento que seja capaz de nos fazer refletir sobre nossa atual "condição humana".

\footnotetext{
1 Professor Associado Da Universidade Federal Rural Do Rio de Janeiro e do PPGeduc-UFRRJ, e-mail carlosbeto.carvalho@gmail.com ORCID https://orcid.org/0000-0003-3408-134X .

${ }^{2}$ Professor Associado da Universidade Federal Rural do Rio de Janeiro, do PPGFIL-UFRRJ e do PPGF-UFRJ. E-mail: fjdmoraes@ gmail.com. ORCID https://orcid.org/0000-0002-2166-8048 .
} 
Às bordas deste inferno dantesco das deficiências cognitivas que nos permitiram mistificar a realidade, em que já não distinguimos o bem do mal, o justo do injusto, a verdade da mentira, cabenos desconfiar de tudo, inclusive da própria desconfiança.

Diante do caos, cabe-nos pensar, sim, pensar, pensar assim... Pensar sempre, mas sem corrimãos, sem essas muletas cognitivas que são as amarras ideológicas. Para Hannah Arendt, pensamento só é pensamento enquanto gera mais pensamento, ad infinitum, e sempre a seu próprio serviço. Neste sentido, pensamento é “inútil”, não está a serviço de nada, de nenhuma religião ou partido, porque está só e somente só a seu próprio serviço.

A ordem escriturística dos textos será sempre arbitrária e linear? A primeira vista nos parece que sim. Contrário a isto e apoiados no pensamento de Hannah Arendt, pressupomos um leitor desobediente, um leitor livre. Assim o sendo, sugerimos que cada leitor ou leitora seguindo o espírito deste dossiê possa pensar sem corrimãos, desobedecendo ao arbítrio dos sentidos impostos. Advogamos que os textos sejam lidos na ordem que lhe aprouver, pois se o sentido da política, segundo Arendt, é a liberdade, o da leitura também o é, porque ler é ato político e prática de liberdade (Paulo Freire) e sem liberdade não há pensamento livre; antes, há servidão voluntária (La Boetie), alienação e deficiência cognitiva.

É do ímpeto da liberdade politica, epistemológica e cognitiva que nasce a ética deste dossiê. Nele buscou-se responder a uma questão - crucial: o de pensar a crise na educação na contemporaneidade a partir do pensamento de Hannah Arendt. Para que o debate em torno a essa questão fosse aprofundado, optamos por convidar autores (na maioria filósofos) afinados à questão proposta. Essa especificidade fundamentada em nosso objetivo acabou por concentrar, não por acaso, a maioria dos autores em uma determinada região do país. Apesar disso, a diversidade e a pluralidade do pensamento foram preservadas e garantidas pela multiplicidade e variedade dos textos que os autores se utilizaram para desenvolver e desdobrar o pensamento político e filosófico de Arendt, resultando daí, acreditamos, uma rica oportunidade para que os educadores e educadoras possam se acercarem da questão em torno da crise atual na educação. Desta feita, por diferentes pontos de vista, que a reflexão sobre essa crise ocorra não de forma monológica, mas dialógica, polifônica, responsiva e responsável.

Por fim, resta-nos dizer que, em cada uma dessas vozes que aqui se expressam livremente a respeito da questão proposta, há de poder ouvir um grito de LIBERDADE e de ESPERANÇA, porque esperança é coisa que não se abandona jamais. Respondemos, então, a Dante com os versos 
do seresteiro que ousa cantar no escuro, o poeta Thiago de Mello, cujo canto destacamos um trecho, versos com os quais terminamos este texto.

\section{Madrugada Camponesa.}

[......

Não vale mais a canção

feita de medo e arremedo

para enganar a solidão.

Agora vale a verdade

cantada simples e sempre,

agora vale a alegria

que se constrói dia a dia

feita de canto e de pão.

[...]

(Faz escuro Mais eu canto- estrofe II)

Que assim seja!

Os organizadores 